\title{
Public television ANd media literacy: The Role of TV ombudsman PRogrammes in Portugal ANd Brazil
}

\author{
Sara Pereira, Jairo Faria \& Clarisse Pessôa
}

\begin{abstract}
Is Media Literacy a dimension of the Public Service of the Media? Does public service television, in Portugal and in Brazil, contemplate Media Education in their policies and grids? Taking these questions as a departure and debating point, we have used sixteen editions of the ombudsman programmes of the public broadcasting companies of Brazil (Empresa Brasil de Comunicação - EBC) and Portugal (Rádio e Televisão de Portugal - RTP) as analysis corpus. In order to examine O Público na TV (The Public on TV) from EBC and A Voz do Cidadão (The Citizen's Voice) from RTP, we have used a set of analysis categories which will allow, among other aspects, to understand the contribution of these programmes to the promotion of Media Literacy of the societies where they are broadcast and of the public they will reach. Generally speaking, the results show that, by developing a role of mediation with the public/audiences, the Ombudsman plays an important role as a Literacy Agent for the Media towards those audiences, even though that role could be reinforced and could express, in a more direct and clear form, the objective of Media Literacy.
\end{abstract}

\section{Keywords}

Media public service; ombudsmen; media literacy

\section{INTRODUCTION}

Considering the presence and importance that the media possess in the everyday life of the 21st century citizen, and that the use that people make of the media may influence their vision and action about and upon the world, the way they participate in the community and in the public sphere, as well as the way they exercise their rights as citizens (Pinto, 2003), several studies and authors have drawn attention to the importance of media education as a process which allows the development of skills towards the use, critical analysis and production of the media.

Media Education or Media Literacy has been considered a fundamental area for the exercise of citizenship. A number of institutions, amongst which are Unesco and the European Union, have put this area on their agendas, trying to draw attention to its social, educational and political importance. The relevance of this area is justifiable due to the importance of the media, both new and traditional, in contemporary society. Among the several roles played by the media, some stand: (1) its importance in the process of construction of culture, in the way that they permit, through the messages they convey, a reproduction of the social structure (Lopes, 2013). Through the media, people create a sense of the World they live in, and develop their identities and representations about 
what surrounds them. (2) The work they do in the selection and hierarchization of information that they broadcast, that is, the work of construction of reality (Pereira, 2000).

This role leads us to the fact that media messages show us a reality that is engineered by the subjectivities inherent to the sociocultural and economic backgrounds of those who create them (Baccega, 2011); therefore, it is important that, when citizens use the media, they are aware that these show us a universe that is edited, redesigned and, up to a certain extent, manipulated (Baccega, 2011). (3) Their role as enhancers of social participation, namely through the creation of media content with resource to digital tools, thus enriching and broadening public discussion of social topics and problems which may otherwise remain silent or be presented only by the perspective of certain media companies.

Once faced with these roles, or functions, it is fundamental that the citizen knows how to critically read the media, so as to take advantage of their potentialities and to face the risks and challenges that may arise from them. Equally important is the awareness of individuals of their rights and duties of freedom of speech and communication, hence trying to build an individual and collective awareness to the matters of production, publishing and content sharing ethics (Buckingham, 2001; Moeller, 2009).

These are, therefore, the objectives of Media Literacy, synthesised by the European commission as "the ability to access the media, to understand and critically evaluate different aspects of the media and media content and to create communications in a variety of contexts" (Commission Recommendation of 20 August 2009).

Once we focus on this definition, we implicitly find four dimensions: access, understanding, assessment and creation. In what concerns access, it refers to the concern about and need to allow universal access to information and communication means and technologies, in such a way that all citizens have an opportunity to be a part of the multimedia reality in which we live (Lopes, 2011).

As for understanding and evaluation, these relate to our skills of critical and conscious use of the media, from the understanding of how to search, select and evaluate the surrounding information. These dimensions transcend the technical and instrumental matters of access, entering the domain of critical thinking, analysis and knowledge of the contents which circulate in the most diverse means of communication (Pinto, Pereira, Pereira \& Ferreira, 2011). Finally, creation comprehends the creative, ethical and autonomous production skills of media content together with the citizens' participation in the and through the different means (Pereira, Pinto \& Moura, 2015). In this regard, Sonia Livingstone (2004) adds that people reach a deeper understanding of the media scenery in which we live when they have the experience of producing media contents themselves.

Several agents and contexts have been summoned to this work of promoting Media Education: family, parents, school, teachers, school and city libraries, town councils, civic associations and the media themselves. As far as these last are concerned, even though it is considered that the promotion of Media Literacy is/should be a role of all the means, no matter their public or private nature, the public service media are attributed 
with a higher responsibility in this function, due to their commitment towards society and the values that they are to defend and promote.

In the next part we will approach the principles and values of public service media, trying to demonstration how they intersect with the objectives of Media Literacy. This article defends that the public service media, by respecting and upholding their inherent principles, may be important agents of Media Education within the public. To support this perspective, we have analysed 16 editions of the programmes $O$ Público na TV, from the EBC Ombudsman, and A Voz do Cidadão, from the RTP Ombudsman. Since these television programmes can be considered spaces for the promotion of Media Literacy by excellence, we have tried to analyse the contributions they offer on this level. Are the Ombudsman television programmes, in Brazil and in Portugal, means of Media Education? This is the question that guides this study and this article.

\section{Public Service media ANd Media Literacy}

Jo Bardoel and Gregory Ferrell Lowe stated in 2007, that "the core challenge facing public service broadcasting [PSB] today is the transition to public service media [PSM]" (Bardoel \& Ferrell Lowe, 2007, p. 9). In effect, in a time characterized by multimedia communication networks, the concept of public service media defines the inherent ecology of communication and of the media better. The concern to revitalize the objectives and the mission of public service media in a multiplatform digital environment has nonetheless deleted the debate on its importance, viability and impact on society. The Finnish professor Gregory Ferrell Lowe stated, in the Conference given in the scope of the annual event Knowledge Exchange, organized by the Media Intelligence Service da European Boadcasting Union (EBU), that "In the media ecology of networked communications, the value of the public service sector is pointedly questioned, strenuously challenged and increasingly uncertain" (Ferrell Lowe, 2016, p. 6).

When gathering the contributions of several authors who have studied and discussed the value and values of the public service media, we could say that this discussion is traversed by topics such as role, objectives, principles, mission and functioning and the financial model. For example, in 1993, Blumer identified a set of six "vulnerable values" which should be protected within public television. These were: quality, diversity, cultural identity, distancing towards financing sources, integrity of civic communication and the well-being of children and adolescents (Blumler, 1993, pp. 57-58). In the same year, in a work published together with Hoffman-Riem, this academic attributes three types of functions to public television: cultural, political and social. In a publication from 1994, Giuseppe Richeri presented the objectives that should orient public television in the confrontation with the new reality brought about by private television: a) "to respond to the diversity of the public demand, offering quality programmes which are alternative to the stereotyped programming of private networks; b) "to promote innovation of programmes, languages and interaction with the public; c) "to represent cultural social and regional specificities which constitute the richness of the country; d) "to inform in a 
balanced, plural and autonomous form about the main political, social and cultural public interest themes" (Richeri, 1994, p. 60). The author stated that these objectives synthesized others presented in all other proposals, which showed the convergence opinions existing in Europe about this matter. In order to reach these objectives, it would be fundamental that public service could count on public financing, while guaranteeing a high degree of independence face to government and maintaining an accountability process towards the public.

The French sociologist Dominique Wolton equally emphasised the social function of television, its fundamental role of social bond, as well as the cultural identity function. Wolton (1997) considered that television helped the elaboration of cultural frames of the contemporary society, being a place of cultural creation and a means of awareness to other forms of culture, thus playing a double function of openness to the world and of preservation of a national identity.

In McQuail's perspective (2003, p. 158), "there has never been a consensual 'theory' of audio-visual public service", considering that the low points of this 'theory' lay in two sources of stress: the necessary independence and accountability for the sums received and for the objectives reached; the relationship between the public interest goals and the desires of the audience in the vast market of the media. As McQuail (2003, p. 159) states, "without objectives of public interest there is no argumentation to continue, but without audiences the public service objectives really cannot be reached".

In Portugal, the debate around public service, especially of television, occurs in the public space recurrently. In 2002, the proposals presented by the XV Constitutional Government, led by Durão Barroso, led to an intense debate on the matter on the streets and in the means of mass communication. It is in this follow-up that a group of researchers from the Communication and Societey Research Centre gathers in the work Televisão e Cidadania (Pinto, 2003, p. 134) a set of recommendations and proposals which "should be regarded by those who think, decide and makes public service television". Among other contributions, they emphasise the idea of "turning social life into the centre of gravity from which public service is thought, structured and materialised" and of "associating the citizens themselves to the idea of public television service, from its political definition to the ways it is materialized and to the assessment of the service rendered" (Martins, 2003, p. 12). The authors present a public service proposal "not only with the public, but from the public and with the public, that is, a television from and to citizenship" (Pinto, 2003, p. 47).

The contributions from these and other authors (Atkinson \& Raboy, 1997; Richeri, 1994) are clear examples of how we have been trying to debate and rethink the objectives, forms and logics of intervention of the public service media. Even though these objectives may have some variants according to the traditions and priorities of each country, generally speaking the preoccupation is centred on the promotion of "public interest", in the diversity (of contents, actors and publics) and in the culture, criteria which intend to be ruled by a quality service.

Those contributions also show that, independently of the time or the context in which this debate takes place, its essence remains practically unaltered. Looking at the 
Declaration of the Core Values of Public Service Media proposed in 2012 by the Operating Eurovision and Euroradio (EBU, 2012), we understand that this proposal reaffirms a set of values already widely debated and proposed, which are:

a) Universality: it aims to reach all segments of society, searching for inclusion and social cohesion. It reaffirms the importance of a plural expression of points of view and ideas, as well as the capacitation of audiences towards their participation in a democratic society.

b) Independence, impartiality and autonomy from the political and economic powers, as well as other influences and ideologies, contributing to an informed citizenship.

c) Excellence: working with high standards of integrity, professionalism and quality, trying to incentive good practices in the media industry and capacitating, preparing and enriching the public.

d) Diversity: betting on the representation of different generations, cultures, religions, majorities and minorities, and promoting the plurality of programme genres and points of view thus contributing to create a more inclusive and less fragmented society.

e) Accountability: through an open and transparent attitude which bets on the advertising of editorial criteria and which admits error correction, subjecting themselves to constant public and of the public scrutiny.

f) Innovation: trying to be a driving force of creativity and innovation, investing in new formats and technologies and in the connectivity with the audiences, participating and shaping the digital future, serving the public (EBU, 2012, pp. 4-5).

The presentation of this core of values, as well as a brief summary of proposals and ideas of some authors who have studied the public service media (PSM), serves the purpose of finding a place for Media Literacy in those values and in the public service mission - is Media Literacy one of the areas in which PSM can present/offer a value which is public and for the public?

The promotion of Media Literacy has been on top of the Digital Agenda of the Operating Eurovision and Euroradio. In the publication entitled Empowering citizenship through Media Literacy: the role of public service media, the OEE tries to express its point of view about the central role that the PSM should play in the promotion of media and digital competences of all citizens. Considering that "understanding how to use the latest media technology and evaluate its content is fundamental to critical understanding and active participation, which are the basis of every democratic society" (EBU Viewpoint, 2012, p. 1), the OEE presents a set of principles for the promotion of Media Literacy by the PSM:

The challenge is to deliver quality PSM content to every section of society: to integrate communities, social groups and generations. Today's digital world is not only for the privileged or media professionals; it enlightens and entertains the elderly and the young, migrants and those who may be socially disadvantaged or live with special needs. (EBU Viewpoint, 2012, p. 1)

In the Portuguese case, in the Contract of Public Service Concession, in the 2008 and 2015 versions, Media Education emerges in the article related to Specific Obligations of the Concessionaire, considering that "It is the Concessionaire's duty, among 
others: h) To participate in activities of Media Education, namely by guaranteeing the broadcast of programmes oriented towards this objective"'. The Portuguese Radio Act (Lei n. ${ }^{\circ}$ 54/2010 de 24 de dezembro) too, considers, in Article 49, that one of the specific obligations of the public service concessionaire is " $f$ ) To participate in activities of Media Education, namely the broadcast of programmes oriented towards this objective".

Also, in the Strategic Guidelines for RTP², the Independent General Council (CGI, 2015) contemplates, in its Specific Strategic Guidelines, in the section A company open to society and to the country, an orientation related to Media Literacy:

35. In accordance with what the Television Act (art. 51, no. 2, I. f), the Radio Act (art. 49, no. 2, I. f) and the Concession Contract establish, and what the Operating Eurovision and Euroradio (OEE) and the European Commission stipulate, to promote media literacy, perceived as a critical training of publics, through an action programme which articulates what it already does (Teaching Portal, Ombudsman programmes, RTP Academy, participation in the Informal Media Literacy Programme, etc.) and what it might do in the future. (CGI, 2015, p. 9)

In both these public service media - television e radio - maybe the most expressive spaces of Media Education are the programmes of the respective Ombudsman - the Viewer's Ombudsman on RTP, and the Listener's Ombudsman on Antena 1 - which we will refer to in more detail in the next part.

As far as RTP is concerned, we may still name the programme Nativos Digitais (Digital Natives) broadcast by RTP between 2010 and 2012 and which is thus referred to in the company's site: "the media cross the space of all social and political life of the country. But understanding where they come from and where they go to is an essential question of our time. RTP2, attentive to the public commitment of explaining which information society we are building, presents Nativos Digitais, a programme aiming to clarify the sharing of knowledge through all networks. Here you can find the protagonists, the companies, the specialists and the final consumers of this new contents cloud". This programme allowed to deconstruct the world of the media, from the newest to the most traditional, approaching different types of contents: information, entertainment, fiction, publicity and media publics/audiences. This bet may have arisen to uphold to the Concession Contract previously referred to, which implicated the broadcasting of programmes oriented towards the objectives of Media Education.

Another public service project to highlight, this one from 2014 and of digital nature, has to do with the Portal Ensina (Teaching Portal), a platform that aims to allow "access to hundreds of RTP contents - of formative and pedagogic scope - meant for students of basic and secondary education, parents and teachers". The portal provides a collection

\footnotetext{
' Obligation also established in the Television Act (art. ${ }^{\circ}$ 51, no. 2, I. f).

${ }^{2}$ These guidelines derive from article $8 .^{\circ}$ of the Radio and Television of Portugal Statutes (Estatutos da Rádio e Televisão de Portugal, S.A.) published in attachment to Act 3/2014, July 9 (Lei n. ${ }^{\circ} 39 / 2014$ de 9 de Julho). That article stipulates that it is the Independent General Council's role to define and publicly divulge RTP's Guidelines, to which the process of choosing the administration council and of the respective strategic project for the company subordinate.
} 
of videos, audios, infographic content and photos produced by the different RTP channels over the last eight decades, with a section totally dedicated to Media Education.

Although this Media Literacy offer from the Portuguese public service media may be commendable, it is a fact that this could go further and be more sustained. In effect, it should not resume to an ephemeral diary of programmes or services, it should instead be framed by a policy of Media Education promotion which is based on its various dimensions - access, content and production/participation analysis - and which had as main role to raise the levels of media literacy of its publics.

In the Brazilian case, the Empresa Brasil de Comunicação (EBC), instituted in 2008 by the Lei 11.652, de 7 de abril (Act 11.652 of April 7), has tried to develop in a context which has not been favourable to its success. Firstly, one should take into account the oligopoly background of private companies which in which the Brazilian media society is immersed, as stated in the research published in November 2015 by Intervozes - Coletivo Brasil de Comunicação Social. According to the study, this concentration occurs in three spheres: 1) by the private appropriacy of a public good; 2) by the market domain; and 3) by political-ideologic domination (Marinoni, 2015). Secondly, one can notice frailties related to its Independence and guarantee as a public communication company. According to Eugênio Bucci (2013), "it aims to do public, non-governmental communication, but it has not got there yet. Its legal conformation does not correspond to the one a real public communication company should have. What it lacks, essentially, is exactly this: independence" (Bucci, 2013, p. 127).

For the researchers Nelia Del Bianco, Carlos Eduardo Esch and Sonia Virgínia Moreira (2013), that perception derives from a "symbolic liability" linked to the image that people of the company as a state company:

The lack of trust of the citizen towards everything that is public, invariably associated to the state structures of government, is notorious. And the perception of what one has of what relates to the state is enhanced by daily experiences of the citizen [which are] marked by the different forms of social exclusion (lack of housing, health, education among others), besides the incapacity and inoperancy of the public administration in providing basic public services satisfactorily. The association between state and something evil also impregnate the vision of public broadcasting. (Esch \& Moreira, 2013, pp. 70-71)

Moreover, recent conjunctural aspects have impaired EBC in what concerns its public function, since the participation and social control mechanisms of the company have been jeopardized by measures adopted by the ruling governments. The Act for the creation of EBC institutes two autonomous organs which allow the participation of the citizens in the company's decisions: The Curator's Council and the Ombudsman. The Curator's Council is formed by representatives of civil society and has autonomy to determine the directives for the contents to be broadcast by the company, as well as to designate important names in the direction. A recent measure (Medida Provisória 744/2016 
- Provisory Measure 744/2016) has extinguished, at least provisionally, EBC's Curator Council, further fragilizing the public character of the institution. In the next point we will present aspects related to EBC's Ombudsman.

Despite these difficulties, EBC, and especially the TV Brasil network, produce contents whose educational character is not usually seen in the higher rated Brazilian networks. Examples of this types of content are the programmes: Ver TV (Watching TV), which broadcasts diversified debates about the television content in Brazil; Observatório da Imprensa (Press Observatory), which critically analysis the action of the media in facts of public matter; and Outro Olhar (Another look) (http://tvbrasil.ebc.com.br/outroolhar/ episodio/outro-olhar-jornalismo-participativo-na-tv-brasil), which stimulates independent producers to send videos of up to two minutes to be broadcast in the main news programme of the network. In addition, it calls attention its dedication to programming devoted to a child-juvenile audience. In a study from the Federal University of Ceará ordered by the EBC's Curator's Council, we can conclude that the network's programmes of this type "show contents which are fundamental to the promotion of the integral development of children, highlighting the concrete possibility of handling formation and fun with balance" (Vitorino, 2011, p. 221).

\section{The ombudsman in the public Service media in Portugal and Brazil}

Ouvidor, Provedor, Médiateur, Garante, Defensor, among others. These are words used to denominate the professionals responsible for receiving opinions, accusations and suggestions from the citizens, working as means of accountability by the population. This position first appeared on Swedish public organs, 1809, named as Ombudsman, which may be translated by "that who represents". The idea was replicated in several countries as form of accountability of the companies, especially in organizations related to the State 3 .

The western means of communication started to make use of this function after 1967 , in the United States. The pioneers of type of initiative were most probably two newspapers from the town of Louisville, in the state of Kentucky. The Louisville CourierJournal and the Louisville Times started to include a column dedicated to the ombudsman, which brought to public, in a commented way, questions raised by the readers about the content conveyed in previous editions of those newspapers. From then on, the idea of ombudsman column was implemented by some of the most important newspapers in the world, as it is the case of the northern American The Washington Post or of the Spanish El País (Maia, 2003).

In Brazil, Latin American pioneer in this type of initiatives, the Folha de S. Paulo was the first newspaper to adopt the ombudsman column, in 1989. This experience inspired other initiatives, as is the case of the newspaper O Povo, from Ceará, which adopted the figure in 1994. These two newspapers maintain until today their weekly ombudsman columns.

3 With the popularization of this type of activity, the different cultures started to conceptualize ombudsman in different forms. Thus, in Portugal, he is called provider, in Brazil, it is common to refer to this professional as ombudsman or listener. The different forms of translating the word ombudsman may indicate the difficulty in establishing the functions and routines of this professional. 
Still in the Brazilian context, the ombudsman experience in broadcasting means is limited to the public company. Created in 2008, the Empresa Brasil de Comunicação $(E B C)^{4}$ possesses an Ombudsman service granted by the company creation act, which in its article no. 20 establishes that:

\begin{abstract}
EBC will count on 1 (one) Ombudsman service, run by 1 (one) Ombudsman, whose role is to promote internal critical assessment of the programming produced or broadcast by it, in respect of the observance of the principles and objectives of the public broadcasting services, as well as to examine and opine about the complaints and reclamations from viewers and listeners referring to programming. (Brasil, 2008, art. 20)
\end{abstract}

The Ombudsman service receives diverse critics, suggestions, compliments and comments from the public from the eight radio stations, two television channels and from the news agency managed by the institution. These requests are registered and analysed in monthly, trimestral and yearly reports and the monitorization of the content is forwarded to the direction of the company in daily bulletins issued by the sector. Even though it is stated in the law (Brasil, 2008, art. 20), the production of Ombudsman service media spaces has not happened frequently. At present, the radio and television programmes are not broadcast and the Ombudsman Column, in Agência Brasil (Brazil's news agency) is only scarcely published.

The EBC's ombudsman service is in its fourth management. The first [seat] was occupied by the journalist, researcher and presenter of the programme Ver TV (Seeing everything) Laurindo Leal Filho, who had the responsibility to structure the first actions of the organ. The second term of the EBC's ombudsman service was occupied by Regina Lima, who brought changes to the structure of the service, organizing the production of reports and developing the radio and TV programmes as well as the Ombudsman column in Agência Brasil. The journalist Joseti Marques, who already played the role of assistant ombudsman, took over the place of General Ombudsman for EBC5 in 2014. The structure of the Ombudsman service is organized in the following manner: 1) Monitorization/Management of the Information: analysis of the contents broadcast on the radio and TV networks and in Agência Brasil; 2) [Customer] service which contemplates a) Serviço de Informação ao Cidadão (Citizen Information Service)(SIC), through which public information regarding the Lei de Acesso a Informações Públicas (Access to Public Information Act) (LAI) is granted; b) External [Customer] Service, referring to critics and suggestions from the public regarding the content broadcast by EBC; c) Internal [Customer] Service, [an] Internal Ombudsman service to attend to the requests of the EBC's professionals.

\footnotetext{
4 Created by Act 11.652 from April 7, 2008 (Lei n 11.652, de 7 de abril de 2008), EBC - Empresa Brasil de Comunicação is responsible for the management of the public service media in Brazil.

${ }^{5}$ Besides the General Ombudsman, the team has another three assistant ombudsmen (one for each area of the company), a clerk who assists in the area of communication, to edit the bulletins and reports, a secretary and two trainees. The EBC's Ombudsman service team is presented in the company's webpage: http://www.ebc.com.br/sobre-a-ebc/ ouvidoria/2012/08/equipe-ouvidoria
} 
In Portugal, the first ombudsman experience happens in 1992 in the sports newspaper Record "more or less accidentally and without continuity" (Oliveira, 2013, p. 173). As from 1990, the Readers' Ombudsman is installed, even though not yet in a regular manner, in two Portuguese newspapers - Diário de Notícias and Público. In 1997, with the reappearance, in the Diário de Notícias newspaper, of the Ombudsman column (signed by the journalist Mário Mesquita), this activity gains some regularity in the Portuguese press (Oliveira, 2013). In the present year of 2016, only Público kept its Sunday edition of the Reader's Ombudsman column. This column ended up being suspended in June this year, in the sequence of the death of Professor Paquete de Oliveira, who played the role of Ombudsman in that daily newspaper.

In the public services of Radio e Televisão de Portugal, the figure of Listener and Viewer's Ombudsman was instituted by Lei n. ${ }^{\circ} 2$ de 14 de fevereiro de $2006^{6}$. According to this legal document, "the Listener's Ombudsman and the Viewer's Ombudsman are designated from among people of recognised professional merit, credibility and personal integrity whose activity in the last five years has been done in the area of communication" (Artigo 23. ${ }^{\circ}-\mathrm{A}$ ); they are both indigitated by the Administration Board of the Rádio e Televisão de Portugal, the indigitated names being subject to the binding opinion of RTP's Opinion Council. Still in accordance to the Law, it is the Listener's Ombudsman and the Viewer's Ombudsman's role, whose terms last two years, once renewable (Artigo $\left.23 .^{\circ}-\mathrm{B}\right)$ :

a) "to receive and evaluate the pertinence of complaints and suggestions from listeners and viewers about the contents broadcast and the respective form of presentation by the radio and television public services"; b) "to give opinions about the complaints and suggestions received, directing them to the administration organs and to others to whom they are directed"; c) "to enquire and form conclusions about the adopted criteria and the methods used in the elaboration and presentation of the programmes and information broadcast by the radio and television public services"; d) "to give listeners and viewers their opinions about the contents broadcast by the radio and television public services"; e) to ensure the edition, in the main programme services, of a weekly programme about matters of their jurisdiction, with the minimum duration of fifteen minutes, to be broadcast at an appropriate time"; f) "to elaborate a yearly report about their activity (Artigo $23^{\circ}$ - D).

On April 18 2006, José Manuel Paquete de Oliveira and José Nuno Martins were the first public figures to take possession as Viewer's Ombudsman and Listener's Ombudsman, respectively. As far as the Television is concerned, Paquete de Oliveira gives place, in 2011, to José Carlos Abrantes, who had taken on the role of Reader's Ombudsman for

${ }^{6}$ The Statute of the Ombudsman is included in Chapter V of Law No. 8/2007, February 14, which restructured the Public Radio and Television service. 
Diário de Notícias, being succeeded, in 2103, by the journalist Jaime Fernandes ${ }^{7}$. On the Radio, the journalist Adelino Gomes, who succeeds José Nuno Martins, takes on the role in 2008, giving it to Mário Figueiredo in 2010. In 2012, Paula Cordeiro is designated the Listener's Ombudsman, function that she still exercised until July 2016 , date on which his second term expired ${ }^{8}$.

Voz do cidadão (The Citizen's Voice) and Em nome do ouvinte (In the name of the Listener) are, respectively, the names of the Viewer's Ombudsman and the Listener's Ombudsman programmes, weekly broadcast on the public television and radio of Portugal 9 .

The experiences above mentioned, referring to the Brazilian and Portuguese context, to which we could join those of other countries, show possibilities and challenges for the development of ombudsman service in broadcasting means. Firstly, one should take into account the specificity of this work. Compared to a press ombudsman, the profession who works on television and radio should take into account not only aspects related to the journalistic content, but also those of an entertainment nature. Besides all this, the person undertaking this job must also consider the amount of content transmitted, the 24 hour monitoring of daily programmes which are usually broadcast - in contraposition to the pages daily printed by newspapers.

\section{Methods}

For the production of this article, we analysed editions of EBC's and RTP's Ombudsman television programmes The content analysis of those productions allowed an approach to the contents broadcast at a certain period, allowing us to verify in which manners those programmes are spaces of promotion of Media Education.

The investigation tries to pursue a line anchored in the Profundity Hermeneutics, methodology developed mainly by John B. Thompson and described in the book Ideologia e cultura moderna (2011). That approach comprehends that interpretation is an intrinsic in the study of symbolic forms, understood as products deriving from social phenomena. In this sense, the ombudsman television programmes of the public broadcasting networks of Brazil and Portugal would be inserted in a historic context of symbolic production.

In this work, we exercised the second analytical phase proposed by Thompson for the interpretation of social phenomena, which is characterized as a formal or discursive analysis of symbolic forms, here represented by the media television spaces of the ombudsman services. The content analysis, in this context, arises as a method which allows the observation of qualitative and quantitative elements of those products, which permits an objective and subjective interpretation according to our proposal. Therefore, in a first moment, we set categories linked to the questions we wanted to analyse, according to the following table.

\footnotetext{
${ }^{7}$ Role unexpectedly interrupted by his death on October 272016.

${ }^{8}$ At the time of writing this new provider was not yet designated.

9 The programme Voz do Cidadão was suspended upon the death of the Ombudsman Jaime Fernandes; we are presently waiting for a new indigitation from the company's administration board.
} 


\begin{tabular}{ll}
\hline \multicolumn{1}{c}{ CATEGORY } & \multicolumn{1}{c}{ ORIentation Questions } \\
\hline Metalanguage & Does the programme mention and analyse the action of the media? In what way? \\
\hline Media criticism & $\begin{array}{l}\text { Is there a critical debate in the content or just a company marketing? What jus- } \\
\text { tifies that? }\end{array}$ \\
\hline Relevance of the sources & $\begin{array}{l}\text { Are the sources interviewed in the programme diversified and relevant for the } \\
\text { debate of the topic in discussion? }\end{array}$ \\
\hline Media Literacy & $\begin{array}{l}\text { Is the information broadcast so as to stimulate the look at critical analysis of the } \\
\text { viewer about the contents he/she sees on television? }\end{array}$ \\
\hline
\end{tabular}

Table 1: Analysis categories of the editions of the programmes O Público na TV and Voz do Cidadão

Using as point of departure the editions of both programmes, it was necessary to make a time cut in the selection of the editions to be analysed. In this matter, we faced a challenge, since the programme O Público na TV, from the EBC's ombudsman, was broadcast for little over two years, between 2011 and 2013, while the programme Voz do Cidadão, from the RTP's ombudsman, which initiated in 2007, is still broadcast. For this reason, we chose to analyse editions broadcast in two months of the year 2013, thus the sample is formed by 16 programmes - eight from EBC and eight from RTP.

The programmes broadcast in the months of April and October were chosen as they were situated in the middle of the semesters, guaranteeing, in principle, a lesser risk of being subject to any transition phase (holidays, changes in the programming grid and/or alteration in the term of the ombudsman).

In the case of EBC, the sample contemplated editions which made trimestral balances - in April, of the first trimester, and October, of the third trimester. In the case of RTP, the terms of two different ombudsmen were contemplated - the programmes of April were presented by José Carlos Abrantes and the ones from October by Jaime Fernandes.

The programmes analysed are referred to in Tables 2 and 3.

\begin{tabular}{lll}
\hline \multicolumn{2}{c}{ ANALYSED EDITIONS OF O PÚBLICO NA TV } \\
\hline EDITION & DATE OF BROADCAST & THEME \\
\hline 079 & $04 / 04 / 2013$ & $\begin{array}{l}\text { Interview with Veet Vivarta - influence of the media in children } \\
\text { and adolescents' socialization }\end{array}$ \\
\hline 080 & $11 / 04 / 2013$ & Noone likes to be edited \\
\hline 081 & $18 / 04 / 2013$ & Balance of trimester 1/2013 \\
\hline 1082 & $24 / 04 / 2013$ & $\begin{array}{l}\text { Accessibility - how public TV serves the population and how the } \\
\text { professionals guarantee its access }\end{array}$ \\
\hline 104 & $10 / 10 / 2013$ & Interview with Isabella Henriques \\
\hline 105 & $17 / 10 / 2013$ & Balance of trimester 3/2013 \\
\hline 106 & $24 / 10 / 2013$ & Interview with Eurico Tavares \\
\hline & $31 / 10 / 2013$ & Communication Cuts \\
\hline
\end{tabular}




\begin{tabular}{|c|c|c|}
\hline \multicolumn{3}{|c|}{ ANALYSED EDITIONS OF VOZ DO CIDADÃO } \\
\hline EDITION & DATE OF BROADCAST & THEME \\
\hline & $06 / 04 / 2013$ & $\begin{array}{l}\text { Commemorative edition of the Day of the Radio on the show ' } 5 \text { para Meia- } \\
\text {-Noite' ( } 5 \text { [minutes] to midnight) }\end{array}$ \\
\hline & $13 / 04 / 2013$ & Election of the Pope \\
\hline & $20 / 04 / 2013$ & Politicians as politics commentators \\
\hline & $27 / 04 / 2013$ & $\begin{array}{l}\text { Commemoration of the day of the Press; Programme 'Uma Semana com } \\
\text { os Media' (A week with the media); Farewell of the Ombudsman (Balance) }\end{array}$ \\
\hline & $05 / 10 / 2013$ & RTP's Audiences \\
\hline & $12 / 10 / 2013$ & How the ERC and the Opinion Council from RTP work \\
\hline & $19 / 10 / 2013$ & $\begin{array}{l}\text { Error in a question of the show 'Quem quer ser Milionário' (Who wants to } \\
\text { be a millionaire); Covering of the municipal elections }\end{array}$ \\
\hline & $26 / 10 / 2013$ & $\begin{array}{l}\text { Critics to a show "O País Pergunta" (The country asks), where the Prime- } \\
\text {-minister was the first guest }\end{array}$ \\
\hline
\end{tabular}

Table 3: Analysed editions of the programme Voz do Cidadão

With the corpus for the analysis in hands, we built a grid with a set of topics/questions to proceed with the analysis of the programmes, having as base the categories previously presented. The filling in of the grid for each programme allowed us to obtain a general sight of each edition at stake. The topics contemplated objective and subjective information. The objective fields comprehended technical and identification information - such as the duration of each segment, the topic presented, the number of the edition and the date of broadcast. The subjective fields registered the perceptions of the authors about the description of the contents and their objectives.

The table below presents that set of topics/questions.

\begin{tabular}{l} 
TOPICS/QUESTIONS UNDER ANALYSIS \\
\hline Programme \\
\hline Edition \\
\hline Date of broadcast \\
\hline Theme \\
\hline Duration (per segment and total) \\
\hline Summary \\
\hline Does the programme talk about and analyse the action of the media? In what way? \\
\hline Is there a critical debate in the content or just company marketing? What justifies that? \\
\hline Are the sources interviewed in the programme diversified and relevant for the debate of the raised topic? \\
\hline Is the information transmitted in such a way that they stimulate a critical look and analysis of the viewer \\
about the contents he/she watches on television? \\
\hline Table 4: Topics/questions under analysis in the editions of the programmes $O$ Público na $T V$ and Voz \\
do Cidadão
\end{tabular}

The next parts will present the results and conclusions deriving from this analysis. 


\section{O PÚbliCo Na TV FROM EBC ANd VOZ do CidADÃo FROM RTP: WHAT CONTRIBUTION TO Media Education?}

In this part, we will present the quantitative and qualitative analysis to the 16 editions of the programmes O Público na TV and Voz do Cidadão. According to the fore mentioned criteria, we intend to determine whether or not these programmes from the public networks of the two countries contribute to the critical formation of the viewers.

\section{a) Metalanguage}

This category aims to verify the way the analysed editions approach the media. Four main focuses of approach were identified in the programmes: 1) specific analysis about the programming contents; 2) debate or interview about themes related to the media; 3 ) institutional information; 4) balance of the ombudsman service activities.

The research showed that the programmes O Público na TV and Voz do Cidadão deal with matters related to the media differently. That difference is a result of the format which the programmes showed in the analysed period. The EBC's programme resorted to debates and interviews with specialists on matters related to the media, made in two editions a balance of the ombudsman service activities and made a programme with institutional information about services paid by the public company. As for the RTP's programme, it focussed on specific conflict resolution related to contents broadcast in the programming of the networks (mainly RTP1), but it also made some editions which resorted to debates and interviews with specialists to present matters related to the media.

The editions of $O$ Público na TV approached the following themes: the influence of the media in children and adolescents' socialization; the risks and challenges of editing on television; a accessibility on public TV; child publicity; right to response; right to communication; media and reality construction; communication and democracy; political cover; press credibility; the place of TV on society; image discourse; television production for youth; critical reading of the media; media and social representations; journalism and manifestations; multiple narratives.

The editions of Voz do Cidadão versed the following matters: publicity to Rádio Comercial [(a private radio station)] in programmes of the public network; television covering of the election of the Pope; politicians as politics commentators; freedom of press; media literacy; audiences of the public TV network; scrutiny organs of the public TV network; errors and quiz shows; plurality in the participation of politicians in public TV network; programmes.

The table below shows the number of editions of each programme which approach the afore mentioned aspects.

\begin{tabular}{llccc}
\hline & $\begin{array}{c}\text { Programming } \\
\text { Contents }\end{array}$ & $\begin{array}{c}\text { Debate or } \\
\text { Interview }\end{array}$ & $\begin{array}{c}\text { Insitutional } \\
\text { Information }\end{array}$ & $\begin{array}{c}\text { Activity } \\
\text { Balance }\end{array}$ \\
\hline O Público na TV & 0 & 6 & 1 & 2 \\
\hline Voz do Cidadão & 5 & 4 & 0 & 0 \\
\hline
\end{tabular}

Table 5: Forms of approach of topics related to media in the programmes O Público na TV and Voz do Cidadão 


\section{b) Participation of the public in the choice of the theme}

In this category we evaluated the degree of participation of the public in the choice of the themes presented in the 16 analysed editions. For that, we divided the sample into editions which had as theme matters incentivized by request of the public (participative choice) and editions which had themes defined by the programme production teams, regardless of the public's request (editorial choice).

We understand, from this analysis, a difference between the choices made by the teams of the Portuguese and of the Brazilian programmes. In general, the editions of $\mathrm{Voz}$ do Cidadão invested on themes based on the viewers' requests, while the programme $O$ Público na TV used more of an editorial choice, devoting to matters not directly bound to the public's request.

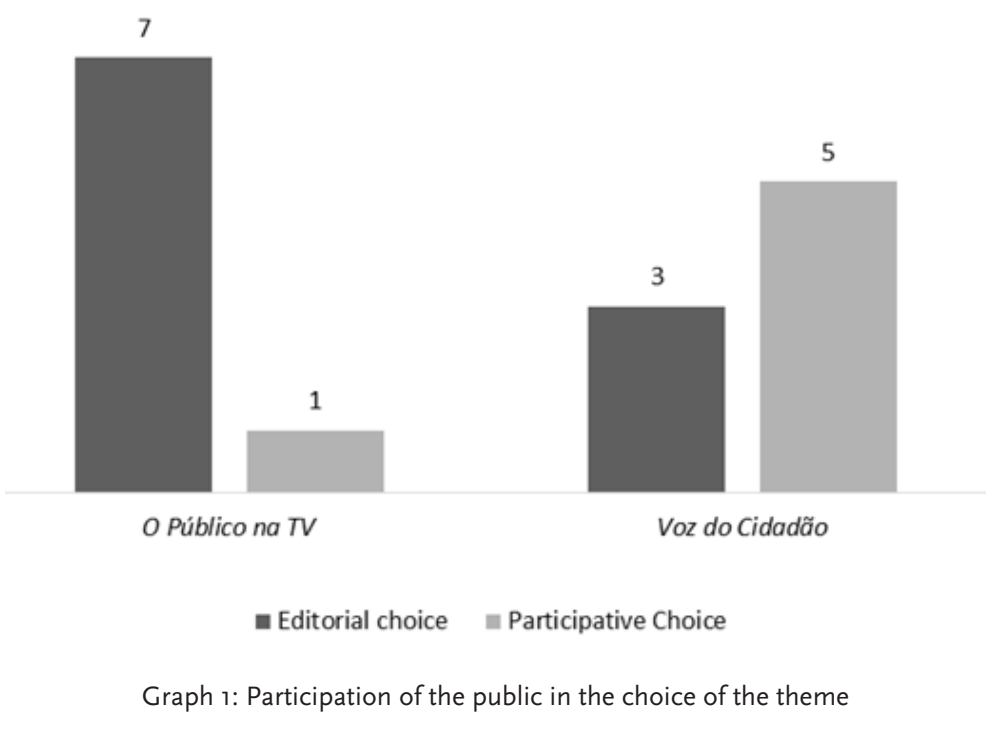

\section{c) Critical Tone}

A third assessment dealt with the plurality of the debates proposed in the analysed editions. That critical tone of the content was assessed taking into consideration five forms of approach: 1) Opinion Column, when there is solely the opinion of the Ombudsman; 2) Represented Participation, when the predominance of the public's opinion is observed; 3) Institutional Defence, when there is predominance of the opinions of the company's professionals; 4) Qualified Debate, when there is a balance between the presented opinions; and 5) Specialized Opinion, when the vision of specialists on the matter is predominant or exclusive.

In what concerns this matter of the analysis, we observed that none of the analysed editions led themselves through the Opinion Column approach. That means that the ombudsmen justified the contents of the programme with the opinions of diverse types of sources, and not only on their own. Nevertheless, we can see that the presenters' opinions (who are, in both cases, the ombudsmen themselves) is used and emphasised, especially in the editions of Voz do Cidadão, where both the ombudsman José 
Carlos Abrantes (responsible for the April editions) and Jaime Fernandes (responsible for the October editions) present their conclusions and personal opinions on the matter at the end of the programme. The ombudsman Regina Lima (responsible for the EBC programme) left her opinion in a more institutionalized and less personal form in the editions of $O$ Público na TV.

In relation to more general data, in the EBC programme, the opinions of specialists on matters related to the media were more present in the content, since a large part of the analysed editions was exclusively devoted to interviews with a specialist. When it comes to the RTP editions, however, we can perceive a more plural debate, since there was quite a balanced representation of the public, RTP's professionals and specialists in matters related to the media.

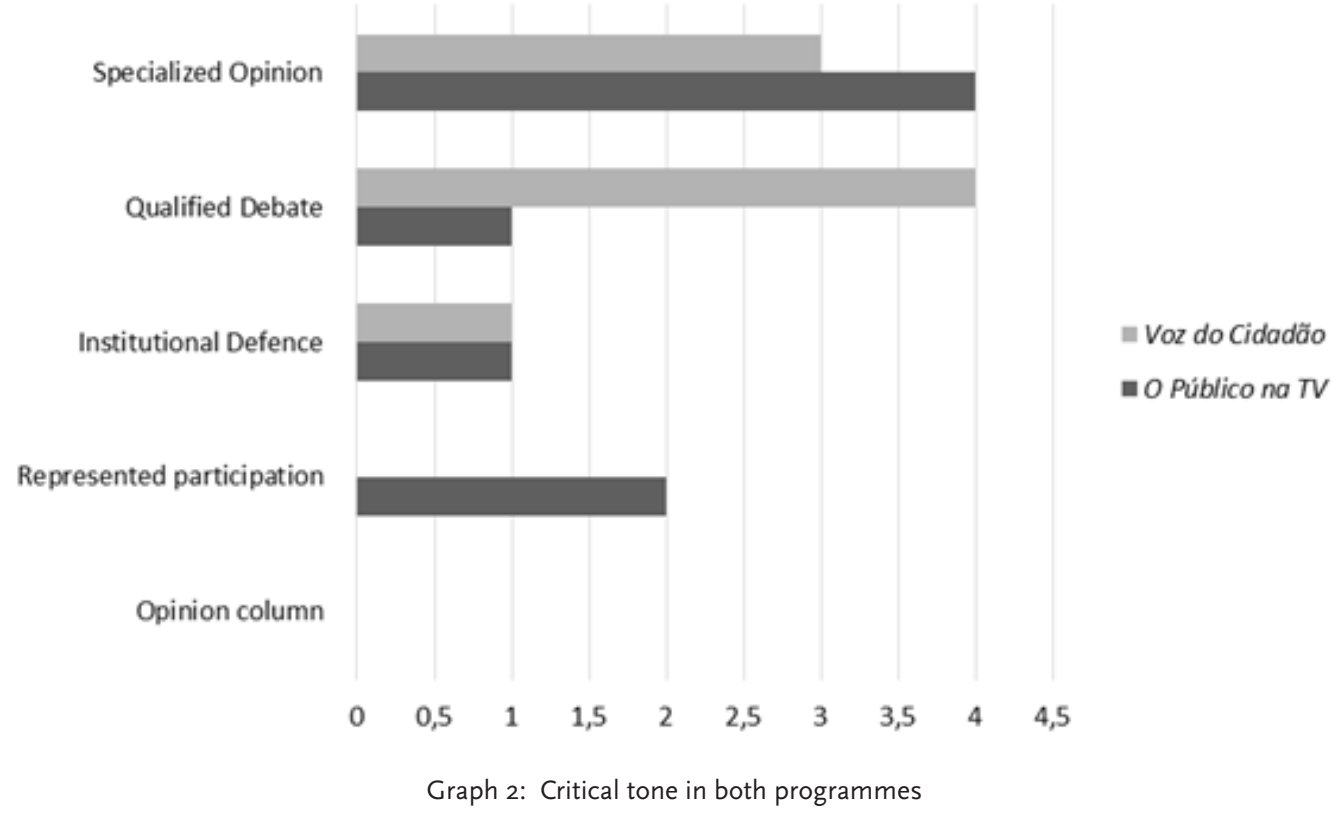

\section{d) Sources}

The data regarding the sources represented in the programmes editions contemplate the previously mentioned information. We identified direct and indirect sources, which were categorized as: 1) participant public; 2) company's professional; 3) specialist; non-participant public; other source category involved in the matter.

The analysis showed that, both in the editions of O Público na TV and of Voz do Cidadão, most of the analysed editions had four or more direct sources represented, the company's professionals and specialists in matters related to the media representing most interviewees. In the case of $O$ Público na TV, what stands is the large amount ot non-participant public, heard through means of the resource "fala povo" ("the pubic speaks") in which bypassers are approached in the street to give their opinion on some matter dealt with in the programme. In Voz do cidadão we can perceive an expressive presence of the company's professionals on interviews, especially of RTP's programming and information directors. 
As to indirect sources, quoted by means of transcription of speeches or messages sent, we can see that the EBC programme used this resource in order to represent the participant public more than the RTP programme.

\section{e) Media Literacy}

Finally, a last analysis criterion assessed whether or not the programmes stimulate the media literacy of their viewers. This category is based on the way the analysed editions were didactic when calling viewers to reflect on matters related to the media.

We concluded that both O Público na TV and Voz do Cidadão are programmes which contribute for Media Literacy, either directly, explicitly stimulating Media Education by inviting the viewers to scrutinize the television programming, or indirectly, through means of approaching different themes related to media criticism. We did not identify any edition which did not stimulate in the viewers a media scrutiny.

\section{FinAL CONSIDERATIONS}

The Media Ombudsman, in the specific case of this work, the Television Ombudsman, undoubtedly represents a strategic area of public service television as far as citizenship and media literacy promotion of the public are concerned, even though the place they occupy in the workings of the public companies RTP and EBC is not always given enough relevance or visibility. In fact, the role of the ombudsman is currently going through a critical moment and some instability in the eyes of those companies. On EBC, the programme has not been produced since 2013 due to a lack of professional human resources, according to the current Ombudsman; on RTP, the unexpected death of the journalist who had that function, led to the suspension of the weekly broadcast of the programme, while we wait for the indigitation of a new ombudsman.

However the difficulties they face, and which are also the result of the political and economic conjuncture of the two countries, the Ombudsman constitutes a value in public service television, contributing to the companies to which this service is attributed to comply with some of the functions and principles which are attributed to them. The promotion of a social responsibility culture in the DNA of the companies and among their professionals; the broader dialogue with the public; the critical reflexivity which it may stimulate, both in the part of the professionals and on the audiences; and the promotion of a larger and better public scrutiny, are some of the principles that these instances may lead to. As seen earlier, these are also some of the values that the Operating Eurovision and Euroradio defends for a media public service closer to citizens.

In what concerns the presented study, the results highlight that Media Literacy is undoubtedly a dimension contemplated by the ombudsman programmes, both in Brazil and in Portugal, even though not directly or explicitly. The approach and debate of topics related to the media, particularly with television, and the analysis of matters often proposed by the public itself, allow viewers a better understanding of those matters, permitting them to develop a more critical and enlightened look of the world of the media, both 
on the level of information and entertainment. The resource of specialized sources of information helped give credibility to the contents debated, thus contributing for a bigger plurality of actors and voices.

With this analysis, somehow quite positive, about the role and the work of these instances in the promotion of Media Literacy of the public, we are not defending that there may not be a higher stake and a higher investment on this level. Either through specific programmes dedicated to the area of Media Literacy, as happened in one of RTP's editions, either through a more explicit treatment of its objectives, the work done also points to the necessity of Media Literacy to assume itself as a clearer and more straightforward objective of the work of the Ombudsman. The extension to digital platforms and the creation of a higher involvement with the public, stimulating its participation, involving it in debates about current matters and furnishing it with instruments which allow a more critical, informed and enlightened reading of the mediatic system, are areas worthy of a higher attention and a bigger investment from the Ombudsman.

\section{BibLIOGRAPHIC REFERENCES}

Atkinson, D. \& Raboy, M. (Eds.) (1997). Public service broadcasting: the challenges for the twenty-first Century. Paris: Unesco.

Baccega, M. (2011). Desafios culturais: da comunicação à educomunicação. In A. Citelli \& M. Costa (Eds.), Educomunicação: construindo uma nova área de conhecimento (pp. 55-70). São Paulo: Paulinas.

Bardoel, J. \& Ferrell Lowe, G. (2007). From public service broadcasting to public service media. Göteborg: Nordicom.

Bianco, N., Esch, E. \& Moreira, S. (2013). Observatório da radiodifusão pública na América Latina: balanço de um ano de atuação. Revista Eptic Online, 15(2), 58-73. Retrieved from http://www.seer.ufs.br/index.php/ eptic/article/viewFile/940/812.

Blumler, J. \& Hoffmann-Riem, W. (1993). Nuevas funciones para la televisión pública. In J. Blumler (Ed.), Television e interes público (pp. 257-275). Barcelona: Bosch Casa Editorial.

Blumler, J. (1993). Valores vulnerables en juego. In J. Blumler (Ed.), Television e interes público (pp. 39-63). Barcelona: Bosch Casa Editorial.

Bucci, E. (2013). Sobre a independência das emissoras públicas no Brasil. Revista Eptic Online, 15(2), 121-136. Retrieved from http://www.seer.ufs.br/index.php/eptic/article/view/944/816.

Buckingham, D. (2001). Media Education: a global strategy for development (Policy Paper prepared for Unesco Sector of Communication and Information). Retrieved from http://portal.unesco.org/ci/en/ev.phpURL_ID=5681\&URL_DO=DO_TOPIC\&URL_SECTION=201.html.

Costa, T. (1991). O relógio de Pascal: A experiência do primeiro ombudsman da imprensa brasileira. São Paulo: Siciliano.

EBU Viewpoint (2012). Empowering citizenship through media literacy: the role of public service media. Switzerland: EBU - European Broadcasting Union.

Gregory, G. (2016). PSM in the 21st century: What value and which values? Switzerland: EBU - European Broadcasting Union. 
Jo, J. \& Gregory, G. (2007). From public service broadcasting to public service media: The core challenge. In G. Gregory \& J. Jo (Eds.), From public service broadcasting to public service media (pp. 9-26). Göteborg: Nordicom, Göteborg University.

Livingstone, S. (2004). What is media literacy? Retrieved from http://eprints.Ise.ac.uk/1027/1/What_is_ media_literacy_(LSERO).pdf

Lopes, P. (2011). Educação para o s media nas sociedades multimediáticas. CIES e-Working Paper, 108. Retrieved from http://www.cies.iscte.pt/destaques/documents/CIES-WP108_Lopes.pdf

Lopes, P. (2013). Literacia mediática e cidadania: Práticas e competências de adultos em formação na Grande Lisboa. Tese de Doutoramento, Instituto Universitário de Lisboa, Lisboa, Portugal. Retrieved from http://repositorium.sdum.uminho.pt/handle/1822/38896.

Maia, K. (2003). Approche comparative de la fonction de médiateur de presse dans les quotidiens brésilien Folha de S. Paulo et français Le Monde. Tese de doutoramento Universidade de Metz, Metz, França. Retrieved from http://www.theses.fr/2003METZoo4L.

Marinoni, B. (2015). Concentração dos meios de comunicação de massa e o desafio da democratização da mídia no Brasil. Análise, 13, 1-28. Retrieved from http://intervozes.org.br/wp-content/uploads/2016/02/ Projeto-FES-Artigo-concentracao-meio.pdf.

Martins, M. (2003). Por uma democracia a vir. A televisão de serviço público e a sociedade civil. In M. Pinto (Ed.), Televisão e cidadania: Contributos para o debate sobre o serviço público (pp. 9-12). Braga: CECS.

McQuail D. (2003). Teoria da comunicação de massas. Lisboa: Fundação Calouste Gulbenkian.

Moeller, D. (2009). Media literacy: Understanding the news. Washington, D.C.: The Center for International Media Assistance (CIMA). Retrieved from http://www.cima.ned.org/wp-content/uploads/2015/02/ CIMA-Media_Literacy_Understanding_The_News-Report.pdf.

Oliveira, M. (2013). Os média ao espelho: a experiência do ombusdman em Portugal e Espanha. In F. Paulino \& L. Silva, M. (Eds.), Comunicação pública em debate: Ouvidoria e rádio (165-181). Brasília: Editora Universidade de Brasília.

Pereira, S. (2000). A educação para os media hoje: alguns princípios fundamentais. Cadernos do Noroeste: Série de Comunicação, 14, 669-674.

Pereira, S., Pinto, M. \& Moura, P. (2015). Níveis de literacia mediática: Estudo exploratório com jovens do $12^{\circ}$ ano. Braga: Universidade do Minho.

Pinto, M. (2003). Pensar e projectar o serviço público com a participação do público. In M. Pinto (Ed.), Televisão e cidadania: Contributos para o debate sobre o serviço público (pp. 33-53). Braga: CECS.

Pinto, M. (2003). Correntes da educação para os media em Portugal: Retrospectivas e horizontes em tempos de mudança. Revista Iberoamericana de Educación, 32, 119-143.

Pinto, M., Pereira, S., Pereira, L. \& Ferreira, T. D. (2011). Educação para os media em Portugal - Experiências, actores e contextos. Lisboa: Entidade Reguladora para a Comunicação Social.

Richeri, G. (1994). La transición de la televisión. Análisis del audiovisual como empresa de comunicación. Barcelona: Bosch, Casa Editorial.

RTP (2016). Provedor do Telespectador (Relatório de Actividade 2015). Retrieved from http://media.rtp.pt/ institucional/wp-content/uploads/sites/31/2015/07/PT-Relatorio2015_Final.pdf. 
Thompson, J. B. (2011). Ideologia e cultura moderna: teoria social crítica na era dos meios de comunicação em massa. São Paulo: Editora Vozes.

Vitorino, I. (Ed.) Pinheiro, A., Torres, C., Pereira, N., Anjos, S. \& Coelho, S. (2011). Relatório Final do Projeto de Monitoramento da Programação Infantil da EBC. Universidade Federal do Ceará. Retrieved from http:// www.ebc.com.br/institucional/sites/_institucional/files/relatorio_final_tv_brasil_grim_ufc.pdf.

Wolton, D. (1997). Pensar a comunicação. Lisboa: Difel.

\section{OTHER REFERENCES}

CGI - Conselho Geral Independente da Rádio e Televisão de Portugal, S.A., Linhas de Orientação Estratégica, 12 de Janeiro de 2015 .

Comissão Europeia (CE) (2009). Recomendação da Comissão sobre literacia mediática no ambiente digital para uma indústria audiovisual e de conteúdos mais competitiva e uma sociedade do conhecimento inclusiva. Recomendação 2009/625/CE de 20 de agosto.

Contrato de Concessão do Serviço Público de Rádio e de Televisão, o6 de março de 2015.

EBC, Empresa Brasileira de Comunicação (2016). Relatório Anual da Ouvidoria 2015.

EBU, European Broadcasting Union (2012). Empowering society (A declaration on the core values of public service media).

Lei n. ${ }^{\circ}$ 2/2006, de 14 de fevereiro, República Portuguesa.

Lei n. ${ }^{\circ}$ 54/2010, de 24 de dezembro, República Portuguesa.

\section{TV sHows}

Nativos Digitais. RTP. Portugal. Retrieved from http://www.rtp.pt/programa/tv/p26916

O público na TV. TV Brasil. Brasil. Retrieved from http://tvbrasil.ebc.com.br/tags/o-publico-na-tv

Observatório da Imprensa. TV Brasil. Brasil. Retrieved from http://tvbrasil.ebc.com.br/observatorio

Outro Olhar. TV Brasil. Brasil. Retrieved from http://tvbrasil.ebc.com.br/outroolhar/episodio/ outro-olhar-jornalismo-participativo-na-tv-brasil

Ver TV. TV Brasil. Brasil. Retrieved from http://tvbrasil.ebc.com.br/vertv

Voz do Cidadão. RTP. Portugal. Retrieved from http://www.rtp.pt/programa/tv/p30350

\section{BIOGRAPHICAL NOTES}

Sara Pereira is an Associate Professor at the Communication Sciences Department and a researcher at the Communication and Society Research Centre of Universidade do Minho, Portugal. She holds a PhD in Children's Studies and she is specialized in Audience Research, Media Literacy and Communication and Citizenship. She is currently the 
head of the Communications Sciences Department and the head of the Communication, Citizenship and Education post-graduate Programme.

Email: sarapereira@ics.uminho.pt

Universidade do Minho - Centro de Estudos de Comunicação e Sociedade

Campus de Gualtar

4710-057 Braga, Portugal

Jairo Faria is a PhD candidate at the Communication post-graduate programme of Universidade de Brasília (UnB). He is a volunteer lecturer at the Communication Faculty of UnB and jointly coordinates the Community Communication and Cultural and Natural Heritage of Planaltina university extension programme. His research interests range from Community Communication to Media Criticism and Public Communication Policies.

Email: jairofaria@gmail.com

Programa de Pós-Graduação em Comunicação da Universidade de Brasília

ICC Norte, Bloco A, subsolo

70910-900 Brasília-DF, Brazil

Clarisse Pessôa is a PhD candidate at the Communication Sciences doctoral programme of Universidade do Minho, Portugal, and also a researcher at the Communication and Society Research Centre. She has lectured Reception Studies in the Communication Sciences Department.

Email: clarisse.amp@gmail.com

Universidade do Minho - Centro de Estudos de Comunicação e Sociedade

Campus de Gualtar

4710-057 Braga, Portugal

* Submitted: 23-02-2016

* Accepted: 10-04-2016 